\title{
Investigating the Strategies that Teachers Used in Written Feedback on Students'Writing in EFL Clssroom Especially at First Year Students of Wachemo University Incollege of Social Science and Humanities
}

\author{
MULUGETA ASNAKEW TADESSE \\ Lecturer in Kebri Dehar University, Qorahay Ethiopia College of Social Science and Humanity, Department of \\ English Language and Literature
}

\begin{abstract}
The main purpose of this study was to investigate the strategies in which teachers used in written feedback on students' writing in EFL classroom especially at first year students of wachemo University in college of social science and humanities. The study used mixed/ qualitative and quantitative research methods. The researcher used qualitative research techniques to collect participants experience and practices on written feedback in writing. Besides this, qualitative approach was also used to ensure the reliability of quantitative data gathering and to examine whether english teachers play relevant role in writing activity. There is no rigid guidelines which bounds about the size of sample, but scholars agree that a sample size of $10 \%$ can work well. Based on this issue the researcher planed to include about 40 research participants from the total of 349 students. Which means from each departments the researcher selected $10 \%$ participants by using simple random method. (i.e Specifically lottery method).however the total number of students in each department were not equal, as a result the researcher selected the participants in relation with their total numbers in all departments. Since the number of teachers were very small and manageable, the researcher included all in their sampling which is known as comprehensive sampling. Through this finding, useful light has been shed on teachers general practice, their writing instruction patterns, and their implementation of feedback in the writing class. There has also been an examination of the students' response and attitude to a feedback that occurred before the finally draft. The finding of the study is more or less positive because, it implies that the strategies of teachers' written feedback were somehow appropriate that contributes for the learners' development of compositions skill. However, the teachers' job is not limited to providing feedback as such, but it extends to ensure that the feedback provided has been taken in to account. The study also identified that, most of students have poor performance in writing and they could not accept their teachers' written feedback. This was the reason for the occurrence of problem in class room. In other way fear not to be judged by others also, factors that affect students' composition.
\end{abstract}

Keywords: transcribing, symbols, flout, rigid

DOI: $10.7176 /$ RHSS/11-7-02

Publication date: April $30^{\text {th }} 2021$

\section{INTRODUCTION}

\subsection{Background of the Study}

Writing is one of the most important language skills which become central in today schools, colleges and universities as a tool for academic success. According to many scholars, writing needs more advanced skill to be good writers and that is why feedback is one of the most important aspects in writing.

Writing is a mental- effort demanding and thus, a time consuming one; " it is far from being a simple matter of transcribing language in to written symbols; it is a thinking process in its own right. It demands conscious intellectual effort which usually has to be sustained over a considerable effort of time." White and Arndt [1991:3].

The term written feedback refers to supplying students clues about written errors in ways which are designed to promote correction by students. According to Keh, [1990], feedback in puts from reader to writer in the form of comments, questions, and other clues which guide the students' writing to produce a meaningfull text, Feedback enable students to strength their writing by taking into account the comments given by their instructors. It can also enhance students' critical thinking skills and encourages them to produced any piece of writing.

The current Ethiopian educational curriculum emphasizes on student centered learning and therefore demands teachers to evaluate and comment students work to achieve the desired objectives. Especially, in teaching writing teachers are expected to provide constructive feedback to their students' writing. According to Cotton (1988), timely and appropriate feedback is vital in increasing students writing ability. So, the feedback process is the best chance to improve students' learning and enhancing their skills as long as it is timely, encouraging and carefully givn to students. The researchers are intended to asses' strategies of teachers writing feedback on students writing . 
Written commentary is a major strategy of feedback teachers provide on students' writing. It is practiced at higher levels and it is praise of criticism. Some of these comments are placed on the margins and thus called marginal comments. Others which are put at the end comments are end comments. Instance of specific positive comments are suggestion or question given in the form of complete sentence. Such as "can you tell me more? I tool have experienced the same thing. This is an excellent choice of works. That is interesting idea"' Wubishet, T. (2009)

Facilitative comments are an other feedback strategy which maintain students' integrity and help them motivated. Instead of writing a comment like "don't the subjunctive here," ask them a question what does the subjunctive form suggest here? Sometimes, students intentionally flout linguistic norms for creative, and meaning full purpose.

\subsection{Statement of the Problem}

Many scholars believed that providing constructive feedback enhances students' learning and assessment out comes. Teachers should play role in providing comments on student writing assignments. Sommers (1982) states three main purpose for which teachers provide feedback on writing: to inform writers as to whether their written products have conveyed their intended meaning to give the student writer a sense of audience (their interests and expectation) and make them ameliorate their writing accordingly.

To offer students an impetus for revision, without comments from a critical reader, writer felt no need to revise thoroughly if they ever think about revision.

In Ethiopian context, it seems as if teachers were not giving an appropriate feedback on students' written works. Particularly in wachemo university, when the researcher were first year students of the university experienced that some teachers were not giving an appropriate feedback on students' written assignment.

The teacher's feedback to students' writing is a key component and crucial parts in the process of writing. It is supposedly the guide which students follow throughout the process of writing and the means which enables them to produce a readable end product. However, what may make teachers get increasingly worried is the fact that the students tends to overlook and ignore the instructor's feedback on their writing.

Most teachers make considerable efforts and spend a long time circling, underlying, and correcting errors, rearranging ideas, and making suggestion for improving the writing piece. Yet surprisingly the students did not take it intoaccount. Basic writing students usually characterized by lack of understanding the rules of formal English writing such as syntax, grammar, spelling punctuation, usage, mechanics, organization and clarity. This was the case which initiated the researchers to conduct the study on assessing English teachers' written feedback on students' basic writing skill.

Some local researchers conducted regarding feedback, but most of them focus on peer feedback in writing activities. For example, Halefrom (2002)in his study, "the effectiveness of peer feedback on the English foreign language students' compositions writing performance', found importance of peer feedback as one way to let student learn by themselves. In addition, Dawit (2003) in his study, "The effect of training students in giving and writing receiving peer feedback on learners' revision types and writing quality", suggested that students should be trained on giving feedback to their peers' writing.

As far as the researcher knowledge concerned, none of the above local researchers focused on teachers' written feedback on students writing skills. The present study differs from the previous researchers as it focused on assessing strategies teachers used in commenting students written feedback. Besides, it focused on the constraints teachers encountered during providing feedback on students' written activities.

\subsection{Objectives of the Study}

\subsubsection{General Objective}

The general objective of this study was to investigate strategies teachers used in written feedback on students' writing in EFL classroom especially at first year students of Wachemo University in college of social science and humanities.

\subsubsection{Specific Objectives}

The specific objectives of this study was:

1) To identify factors that hinder teachers written feedback practice

2) To explore how teachers gave feedback on students writing

3) To assess the appropriateness of written feedback given by teachers on students writing skills

\subsection{Significance of the Study}

The researcher believed that this study has a great advantage to develop students' attitudes towards writing and what kinds of practices they need to develop their writing skills. The study renders good understanding about writing skills for the students, teachers as well as others who read the finding of the study. This study also helps 
the students to know the thing that expected from them to be effective in writing. It also provides solution for a certain problems regarding teaching of writing skills.

\subsection{Scope of the Study}

Since it was difficult to assess teacher's strategies of written feedback on students writing skill in all university, this study particularly conducted on first year students of social science and humanities at Wachemo university in which the researcher live in.

\subsection{Methodology of the Study}

In order to gather the relevant data, the researcher used qualitative and quantitative methods. The data collected from close-ended questions in the questionnaire was analyzed quantitatively through table and percentage. On the other hand the data gathered by open-ended questions and document analyzes were analyzed qualitatively by using words.

\subsection{Organization of the Paper}

This researche is composed of five chapters. The first chapter provides insights in to the important of basic Writing skills in general. It includes definition of writing skill, and teachers' role in this process. It also deals with issues about the notion of feedback such as definition and purpose of feedback with its conditions that insure its effectiveness. Chapter two, deals with description of review of related literature. Chapter three of this study designed to include detail description of the research design and methodology. Again chapter four of the study was analysis and interpretation of data. Finally, conclusion and recommendation of the study presented in chapter five.

\subsection{Limitation of the Study}

The participants that intended to be included in the study may not have appropriate level of cooperation, which means some of teachers were reluctant to show students' document which kept in their office. In other way lack of students' interest in giving the required information during data collection process.

\section{Research Methodology and Design}

\subsection{Research Design}

This research was designed to asses strategies of teachers' written feedback on students' basic writting skills: the case of first year students' of Wachemo university in focus. The researcher intended to describe the way how writing teachers gave feedback for their students, and how students perceive teachers' written feedback.

\subsection{Research Methodology}

The methodology of this research was mixed because we need to applied both qualitative and quantitative research methods. The researcher used qualitative research techniques to collect participants experience and practices on written feedback in writing. Besides this, qualitative approach was also used to ensure the reliability of quantitative data gathering and to examine whether english teachers play relevant role in writing activity.

\subsection{Subject of the Study}

The subjects of this study were first year college of social science and humanities students of Wchemo university. There were 349 students in this college. Among them 172 students were males and 177 students were females and the number of teachers who gave basic writing in this college were 6 . all were males.

\subsection{Sampling Techniques}

There are six departments under college of social science and humanities. They are: sociology, History, English, Civics, Geography, and psychology. There is no rigid guidelines which bounds about the size of sample, but scholars agree that a sample size of $10 \%$ can work well. Based on this issue the researcher planed to include about 40 research participants from the total of 349 students. Which means from each departments the researcher selected $10 \%$ participants by using simple random method. (i.e Specifically lottery method).however the total number of students in each department were not equal, as a result the researcher selected the participants in relation with their total numbers in all departments. Since the number of teachers were very small and manageable, the researcher included all in their sampling which is known as comprehensive sampling.

\subsection{Data Collection Instruments}

For the purpose of getting relevant information about matter of this study questionaire and document analysis were employed. 


\subsubsection{Document Analysis}

This data collecting instrumet was used as a major tool for this study. The purpose of this tool was to find out the strategies teachers used on written feedback and to examine the appropriatness of feedbacks given. Thus, the researchers collected 3 students' written works or assignments, and analysised them based on the concepts of written feedback given by english teachers.

\subsubsection{Questionnaire}

This techniques was used as supportive tool for this study. It was intended to investigate teachers' experience towards giving feedback on students' written works or assignments. In order to gathere the relevant information, the researcher prepared six close-ended and two open ended question for students and four close-ended and three open-ended questions were prepared for English teachers who were giving basic writing skill. The close-ended questions were prepaed to get short and clear answers, while the open-ended question were prepared to get further information from the respondent. In addition, it was expected to generate data related to the constraints that hinder teachers from giving appropirate written feedback on students'writing.

\subsection{Data Collection Procedure}

In order to collect the necessary information the researher planned to adapt the following three steps. First, the willingnesss of teachers for cooperation was asked. Then, the commented assignments of students were collected and analysed before adminstering the questionnaire. This was done as the researcher assumed that if the questionnaires were distributed first, the respondents may be informed and may not give all the students works with important information.

Finally, questionnaire was distributed to the teachers and students. This could help to identify challenges encountered in commenting students' writing.

\subsection{Data Analysis Procedure}

Data was analysed in integrated manner using numbers, percentage and narration. The data which collected from questionnaire were analysed in numbers and percentages. The data which collected from document analyses was described in words in a way they could answer the research questions.

\section{Data Analysis and Interpretation of Students' Responses on the Questionnaires}

For this study 40 students were taken as a sample out of 349 students'. These 40 students were able to fill the prepared questionnaires. All questionnaires were correctly complied,and 6 basic writing teachers filled the prepared questionnaires. The findings of the study presented in the following tables.

\section{Table 1 Students' response on how often their teacher gave feedback}

\begin{tabular}{|l|l|l|l|l|}
\hline No & Item & Alternative & No of respondent & Percentage \\
\hline \multirow{3}{*}{1.} & How often does & A very often & 4 & 10 \\
\cline { 3 - 5 } & $\begin{array}{l}\text { your teacher give } \\
\text { feed back to your } \\
\text { written work? }\end{array}$ & B often & 19 & 47 \\
\cline { 3 - 5 } & & C sometimes & 14 & 35 \\
\cline { 3 - 5 } & D rarely & 3 & 8 \\
\hline & - & - & - \\
\hline
\end{tabular}

As table one shows, the highest number of respondents, $47 \%$ said that the teacher gave written feedback on students' composition "often", $35 \%$ of them responded that the teacher gave written feedback only "sometimes", $10 \%$ of them also replied that the teacher gave written feedback on students' work "very often", and the remains $8 \%$ replied that the teacher gave written feedback for the learners "rarely". According to the majority of respondents the researchers observed that teachers gave written feedback for the learners frequently.

Table2 Students' response whether the teachers' written feedback was appropriate or not

\begin{tabular}{|l|l|l|l|l|}
\hline No & Items & Alternative & No of respondent & Percentage \\
\hline 2 & $\begin{array}{l}\text { Does your teacher gave } \\
\text { appropriate feedback on written } \\
\text { text? }\end{array}$ & A. Yes & 31 & 77 \\
\cline { 2 - 5 } & & B. No & 9 & 23 \\
\hline & Total & & 40 & 100 \\
\hline
\end{tabular}

As it is indicated in table two, the majority of respondents replied that their teachers' gave appropriate feedback on their written paper, $77 \%$ of them replied "yes", on the other hand $23 \%$ of the respondent replied that their teachers did not give appropriate feedback for the learners.

For the majority point of view, the researchers understood that the teacher pay more attention about the importance of written feedback and he or she gave feedback for students' clearly. So, students can improve their writing skill properly. 
Table 3. Students' response whether the teacher had discipline problem or not while he/she gives written feedback

\begin{tabular}{|l|l|c|l|l|}
\hline No & Items & Alternative & No of respondents & Percentage \\
\hline 3 & $\begin{array}{l}\text { Does your teachers have discipline problem while } \\
\text { he or she gives written feedback? }\end{array}$ & A. Yes & 17 & 42 \\
\cline { 2 - 4 } & Total & & 23 & 58 \\
\hline & & 40 & 100 \\
\hline
\end{tabular}

As it is pointed on table three, $58 \%$ of the respondents confirmed that the teachers have not discipline problem while he/she gave written feedback on students' papers or written works. Whereas, about $42 \%$ of them said that the teachers have a problem while he/she gave written feedback on students' composition.

From the above paragraph, the researcher understood that one of the possible reason for giving different response can be due to learners personal perception this means the teachers style of giving feedback might good for some students, but vague and unclear for the rest $\backslash$.

Table 4: Students' responses on teachers' perception

\begin{tabular}{|l|l|l|l|l|}
\hline No & Items & Alternative & No of respondents & Presentation \% \\
\hline 4 & $\begin{array}{l}\text { Does your teacher account the } \\
\text { students attitude and level when } \\
\text { he/she provide feedback? }\end{array}$ & A. Yes & 22 & 55 \\
\cline { 2 - 4 } & B. No & 18 & 45 \\
\hline & Total & 40 & 100 \\
\hline
\end{tabular}

As table four depicts that, more than half of the respondents $(55 \%)$ gave their responses that the teachers account students' attitude and level when he/she provides written feedback. Whereas, $45 \%$ of the respondents replied that the teachers did not account students' level and attitude when he/she gave written feedback for the learners.

From table four the researcher observed that, most of the teachers considered students level and perception during feedback processes.

Table 5: Students' response whether the teachers returned students written assignment on time or not

\begin{tabular}{|l|l|l|l|l|}
\hline No & Items & Alternative & No of respondents & Percentage $\%$ \\
\hline 5 & $\begin{array}{l}\text { Does your teacher return any } \\
\text { written assignment with in a short } \\
\text { period of time? }\end{array}$ & A. Yes & 19 & 48 \\
\cline { 2 - 4 } & & B. No & 21 & 52 \\
\hline & Total & 40 & 100 \\
\hline
\end{tabular}

Based on table five, the highest number of respondents (52) agreed that the teacher did not returne students' compositions or written assignment with in a short period of time where as, $48 \%$ the respondents forwarded that the teachers returned students' written assignment within a short period of time.

Table 6: Students responses about the better way to improve students writing skill

\begin{tabular}{|l|l|c|l|l|}
\hline No & Item & Alternative & No of respondents & Percentage \% \\
\hline 6 & $\begin{array}{l}\text { Which one is better to } \\
\text { improve your writing? }\end{array}$ & $\begin{array}{l}\text { A. Oral feedback of your } \\
\text { instructor }\end{array}$ & 13 \\
\hline \multirow{2}{*}{} & & $\begin{array}{l}\text { B. Written feedback of } \\
\text { your instructor }\end{array}$ & 23 & 58 \\
\cline { 3 - 5 } & C. Peer feedback & 4. & 10 \\
\hline & Total & 40 & 100 \\
\hline
\end{tabular}

Table six reveals that, the majority of respondents (58\%) replied that the way of written feedback for the learners were very important and crucial to improve their writing abilities. On the other hand, $32 \%$ of them replied that oral feedback is the better way to encourag students to raise effective compositions. Lastly, a few respondents $10 \%$ of them replied that, peer feedback is the best way to enhance students' writing abilities. Based on students' responses the researchers observed that teachers' written feedback is the easy way as well as the best way for learners to improve their writing skil

\section{Students' suggestion about the important of written feedback}

Most respondents responded that written feedback is important to improve their writing skill, and they added that written feedback played a vital role for the improvement of students writing skill. Some others responded that because writing is a difficult skill they needed to have written feedback from their teachers. In addition to this the respondents said that the feedback might be positive and negative, both are important for them to improve 
their writing skill. Therefore, this shows that students understood the teacher written feedback helps students' to improve their written activity.

\section{Students' feeling when they received written feedback from their teacher}

All respondents said that, when their teachers gave feedback they felt happiness because the teachers' written feedback help them to correct their mistake and motivate to ask themselves about correcting errors. It showed them the way of correcting their errors and helps to improve their writing skill. Therefore, students felt happiness on teachers' written feedback.

\subsection{Analysis and Interpretation of Teacher Responses to the Questioners}

Table 1: Teacher responses on students' consideration about writing feedback

\begin{tabular}{|l|l|l|l|l|}
\hline No & Items & Alternative & No of respondents & Percentage \% \\
\hline 1. & $\begin{array}{l}\text { Do students consider the written } \\
\text { feedback given on their work as a } \\
\text { source of improvement? }\end{array}$ & A. Yes & 4 & 67 \\
\cline { 3 - 5 } & B. No & 2 & 33 \\
\hline & Total & 6 & 100 \\
\hline
\end{tabular}

Among the above respondents' $67 \%$ of them replied that, students considered writing feedback which is given by the teacher as a source of further improvement. Whereas $33 \%$ of them answered that students' do not consider teacher written feedback as a source of further improvement. So the researchers understood that most students interpret teachers' written feedback in a positive way.

Table 2: Teachers attention to the form and content of written feedback

\begin{tabular}{|c|c|c|c|c|}
\hline No & Items & Alternatives & No of respondents & Percentage $\%$ \\
\hline \multirow[t]{4}{*}{2} & \multirow{4}{*}{$\begin{array}{l}\text { How often do you give attention } \\
\text { to the form and content when } \\
\text { you give written feedback for } \\
\text { students? }\end{array}$} & A. Very often & - & \\
\hline & & B. Often & 4 & 67 \\
\hline & & C. Sometimes & 2 & 33 \\
\hline & & D. Rarely & & \\
\hline & Total & & 6 & 100 \\
\hline
\end{tabular}

According to the data in the above table, $67 \%$ of the respondents replied that, teachers gave attention to the form and content while he/she was providing written feedback was "often". On the other hand, 33\% of the respondent replied that, teachers gave attention to the form and content while he/she was giving written feedback was "sometimes". As the researchers infer from the responses, it seems that the teachers gave attention when they gave written feedback for the learners, because form and contents are the most important methods.

Table 3: Teachers response on students' interest about written feedback

\begin{tabular}{|l|l|l|l|l|}
\hline No & Items & Alternative & No of respondents & Percentage \% \\
\hline \multirow{3}{*}{3.} & Are you students interested to & A. Yes & 2 & 33 \\
\cline { 2 - 4 } & accept any written feedback? & B. No & 4 & 67 \\
\hline & Total & 6 & 100 \\
\hline
\end{tabular}

As it's indicated in table three, $67 \%$ of the respondents agreed that, students do not have interest to accept teachers written feedback. But $33 \%$ of the respondents replied that, students have interest to accept teachers' written feedback. From the above table the researchers understood that, most students were not aware of about the important of teachers' written feedback. Therefore, teachers should give emphasis about the importance and the role of feedback.

Table 4: Teachers response on the strategies of written feedback

\begin{tabular}{|c|l|c|c|c|}
\hline No & Items & Alternative & No of respondents & Percentage \% \\
\hline \multirow{2}{*}{4} & Which strategy of & A. Corrective feedback & 1 & 17 \\
\cline { 2 - 4 } & $\begin{array}{l}\text { written feedback } \\
\text { is more important }\end{array}$ & B. Facilitative feedback & - & - \\
\cline { 2 - 4 } & C. Evaluative feedback & - & - \\
\cline { 2 - 4 } & D. All are important & 6 & 83 \\
\hline & Total & \multicolumn{2}{|l}{} &
\end{tabular}

What the researcher observed from table four was the majority of respondents $83 \%$ of them replied that, all strategies were important to motivate and improve the learners written feedback/ writing ability. However, $17 \%$ of them answered that, corrective feedback is more important strategies to give written feedback on students' written activities.

Teachers' perception about the effects of positive and negative feedback

As teachers revealed about questions, the effects of positive and negative feedback were different on students' attitude. Based on the respondents, positive feedback played a big role on students' perception because positive 
feedback is the way to motivate students to write effective composition. Whereas, negative feedback is a factors that can affect students' writing ability, because when the teachers are commenting students' negatively they were easily Discourage. However, a few respondents suggested that negative feedback has advantage for the learners to improve their writing skill if the teacher used it rarely.

\section{Teachers' motivation while he/she gave written feedback}

The majority of respondents answered that teachers stimulate to write effective written work by using different methods. As they implied that positive feedback is the way of motivating students on their writing ability. Teachers' feedback should be positive even if students made different errors on their written papers. For example, praising is the key word to encourage students. Suggesting this idea Kamla (cited in Mamo, 2001) asserted that "teachers must sugar coat at the bitter pills of criticism with praise". In addition to this, the respondents gave their opinion that the teachers can encourage students by saying "very good", "I like this very much", "This is good try", Tell me more about this" and so on.

\section{The constraints that encountered teachers during commenting students' written exercise}

The respondents answered that, the majority of students' hand writing is not neat and it is difficult to comment. Again the numbers of students are sometimes not manageable to comment everything. In addition to this it was time consuming to give comment for learners one by one, and lack of giving more practical work for the learners.

\subsection{Data from Document Analysis}

In addition to the questionnaires, the researchers made document analysis based on students' composition or assignments papers in order to have second hand information and make the study more objective and real. The researcher analysis laid on strategies of teachers' written feedback on students' papers.

Depending on this data collecting instruments, the researcher analyzed students' paragraphs or essay writing assignment composition and short answer test and quiz papers which was corrected by three different instructors from different departments of other social science and humanities.

As the researcher analyzed students' written assignments, the teachers gave different strategies of written feedback for them. Forexample, the teacher used corrective feedback on students'written papers to identify the errors which are made by students. The teachers pointed out the errors by writing grammar errors, contextual errors,spelling errors, punctuation errors and subject verb agreement. In addition to this, the teacher pointed out students written errors, the teachers also used directive feedback. In this feedback strategy, the teachers were point out errors by making bracket to show a misplaced word and indicating its proper, by underlining the word, and the teachers also crossed out the expression and provide the correct structure. Supporting this idea, Henrickson (1980) asserted that, we use this correction treatment when "we assume that it is difficult for students to correct certain errors." According to this method, teachers underline a word and provide a correction or brackets misplaced words to pointend out its exact place in the sentence. Not only this but also the teacher showed students' errors by making a circle and by putting question mark at errors.

The researcher also analyzed that the teachers did not use much constructive criticism to motivate students for future writing papers. This implies that, students lost moral supporting words like "good", "I like this more", etc from their teacher. However, constructive criticism or moral supporting is the key strategy to motivate stude

\section{Conclusion and Recommendation}

\subsection{Conclusion}

This chapter includes the results yielded by the two research instrument used in the current study. Through this finding, useful light has been shed on teachers general practice, their writing instruction patterns, and their implementation of feedback in the writing class. There has also been an examination of the students' response and attitude to a feedback that occurred before the finally draft. The finding of the study is more or less positive because, it implies that the strategies of teachers' written feedback were somehow appropriate that contributes for the learners' development of compositions skill. However, the teachers' job is not limited to providing feedback as such, but it extends to ensure that the feedback provided has been taken in to account. The study also identified that, most of students have poor performance in writing and they could not accept their teachers' written feedback. This was the reason for the occurrence of problem in class room. In other way fear not to be judged by others also, factors that affect students' composition.

\subsection{Recommendation}

Based on conclusion and the view of different scholars discussed in review of related literature, the following recommendation is made.

* Teachers need to construct encouraging comments which trigger the learners to utilize the feedback given and to avoid students' disregarded of written comments. 
* Teachers need to have a general idea about what their students expect from their feedback.

* Teachers should return students' written assignments within a short period of time, because students can correct their written errors immediately.

* Teachers should give constructive criticism for their students and motivate them for future writing tasks.

* Students should participate in a group discussion with their peers to do any written task which is given by their teacher. And they should accept their teachers' written feedback positively.

* When teachers provide feedback for the students, they should take in to account the learners' attitude, activation, personality and language learning history.

* Teachers should not give confusing, arbitrary and in accessible comments (feedback) for their students rather they exert the at most efforts to make their comments very clear.

\section{REFERENCE}

(Malme,2001:145). Feedback strategies for interactive learning tasks third edition 12,2006 from http://WWW.nwre/ org/sepd/sirs/2/topsyn2.html. and communication, 33,148-156.

Wubishet, T. (2009). Study on the impact of writing skill. Unpublished BA thesis: Gondar University

Cotton,K. (1988). Teaching composition: Research on effective practices. Retrieved July

Dawit Assefa, (2003). The effect of training students in giving and receiving feedback on Halefom Asheborom, (2002). The effectiveness of peer feedback on EFL Students'

Keh,C. (1990). Feedback in writing process, a model and methods for implication. New York Lawrence Erlbaum associate Learners' revision type and writing quality: MA Thesis, Addis Ababa University

Sommers,Nancy. (1982). Responding to students writing. College composition

White,R. and V. Arndt. (1991). Process writing, Harlow, UK: Longman. 